\title{
NACIONALNI PROGRAM IZOBRAŽEVANJA ODRASLIH
}

\section{Vsebinske podlage za določanje strateških in operativnih ciljev}

V

prispevku bomo predstavili vsebinske podlage ${ }^{1}$ za določanje strateških in operativnih ciljev nacionalnega programa izobraževanja odraslih. Povzeli smo jih iz:

- raziskave Odločilni globalni dejavniki razvoja Evropske skupnosti (v nadaljevanju EU) po letu 1992 (I),

- izidov Okrogle mize evropskih industrialcev 1995 (II),

- usmeritev razvoja izobraževanja v Beli knjigi EU in skupnih temeljev razvoja izobraževanja v državah Organizacije za ekonomski razvoj in sodelovanje ( $\mathrm{v}$ nadaljevanju OECD) (III),

- Deklaracije in Akcijskega načrta Svetovne konference o izobraževanju odraslih, Hamburg, julija 1997 (IV),

- Sporočila ministrov OECD, Pariz, 1996 (V), - umestitve vloge izobraževanja odraslih $\mathrm{v}$ slovenskih razvojnih dokumentih (VI),

- koncepcije in strategije vseživljenjskosti učenja (VII)

in ob tem upoštevali izbrane kazalnike o razvoju izobraževanja odraslih v zadnjem desetletju (VIII).

\section{GLOBALNI DEJAVNIKI RAZVOIA EVROPE}

V raziskavi Odločilni globalni dejavniki razvoja Evrope po letu 1992 (The European Challenges Post, 1993) je dvanajst državnih inštitutov ${ }^{2}$ in precej predstavnikov poslovnega sveta opredelilo odločilne »dejavnike oblikovanja « dolgoročne prihodnosti Evropske skupnosti in njenih članic. Po mnenju državnih inštitutov bodo oblikovali prihodnost Evrope ti globalni dejavniki:

- Solidarnost in družbena enakost: temeljni problem sodobnih razvitih družb ni doseganje večje storilnosti, temveč ohranjanje in ustvarjanje dovolj visoke stopnje družbenega povezovanja. Tradicionalne oblike solidarnosti usihajo, novih še ni ali pa jih ne znamo identificirati. Urejanje trga je socialno dezintegrativno, posameznika izloča in preprečuje možnosti socialne identitete. Doseganje soglasja med socialnimi partnerji o socialni solidarnosti je lahko učinkovito sredstvo proti razdelitvi družbe ${ }^{3}$ na tiste, ki so zaposleni na primarnem, in druge, ki so zaposleni na sekundarnem trgu delovne sile, ali so brezposelni; med mladimi in starejšimi; med avtohtonimi in priseljenimi prebivalci, med takimi, ki imajo dovolj temeljnega znanja za spreminjanje poklicev, za ekonomsko dejavno in socialno neodvisno Ključno vlogo $v$ razvoju Evropske skupnosti bo imelo izobraževanje. življenje, in takimi, ki tega znanja nimajo.

- Ekonomski dejavniki (mednarodna tekmovalnost, tehnološki napredek, prenos tehnologij, hitrejši pretok informacij), kulturni (nove družbene prioritete, demografske spremembe, migracijski tokovi, narodna identiteta, varstvo okolja) in politični dejavniki (včlenjevanje $\mathrm{v}$ evropske povezave, procesi političnega odločanja, potreba po povečanju udeležbe prebivalstva pri odločanju, nujnost razvoja novih oblik demokratičnega odločanja).

Pri vseh globalnih dejavnikih imajo po mnenju inštitutov ključno vlogo izobraževanje, usposabljanje in informatika.

V vrsti poročil iz poslovnega sveta so ugledni predstavniki evropskega gospodarstva spregovorili o uresničevanju skupne evropske vizije. Poslovneži sprejemajo t. i. socialni model kapitalizma, po katerem je socialno zdravje cilj, ekonomsko zdravje pa poglavitno sredstvo za
Olga Drofenik vodja projekta Nacionalni program izobraževanja odraslib Andragoški center Slovenije 
doseganje tega cilja. So pa povsem pragmatični, doseči želijo neko sprejemljivo konkurenčnost na svetovnem trgu (ne razmišljajo toliko o tekmovalni prednosti, kakor o tem, kako doseči raven svojih tekmecev (Japoncev in Američanov); najpogosteje omenjajo štiri področja: izboljšanje infrastrukture (ceste, železnice, energetika in telekomunikacije, infrastrukturne storitve, informacijsko omrežje), tehnologijo, več inovacijskih procesov in gospodarski razvoj. Pri tem poudarjajo vlogo izobraževanja, usposabljanja in učenja jezikov.

Razlika med pričakovanji in napovedmi, med inštituti in poslovneži je $\mathrm{v}$ tem, da imajo inštituti vizijo prihodnje Evrope. Ta zajema po besedah J. Delorsa, ki je napisal uvod k poročilu o raziskavi, tekmovalnost, ki se ne meri zgolj s stališča storilnosti posameznih podjetij, temveč s kvalitetnimi merili, kakor so standard izobraževalnega sistema, kakovost družbenega dialoga, raven infrastrukturnih storitev. Poslovni svet pa gleda na prihodnjo Evropo bolj pragmatično: vidi jo $v$ razvijanju skupnega evropskega trga, ustvarjanju čezevropskih omrežij, sodelovanju pri raziskovalnem delu, izboljšavah v usposabljanju delovne sile. Poslovneži menijo, da je zagotavljanje usposabljanja in vseživljenjskega učenja bistvenega pomena in ne more biti prepuščeno zgolj skrbi državnih in regionalnih oblasti. Prepričani so, da sta temeljno izobraževanje in vseživljenjsko učenje poglavitnega pomena za evropsko gospodarsko blaginjo. Niso pa si edini $\mathrm{v}$ tem, kdo naj prevzame odgovornost za ta področja.

$\mathrm{V}$ inštitutih posameznih držav poudarjajo, da so ekonomija, tehnološke inovacije in kultura medsebojno odvisna področja, ki se skupno razvijajo, pri tem pa ima pomembno vlogo izobraževanje (Belgija); da se vrednote $\mathrm{z}$ izo-

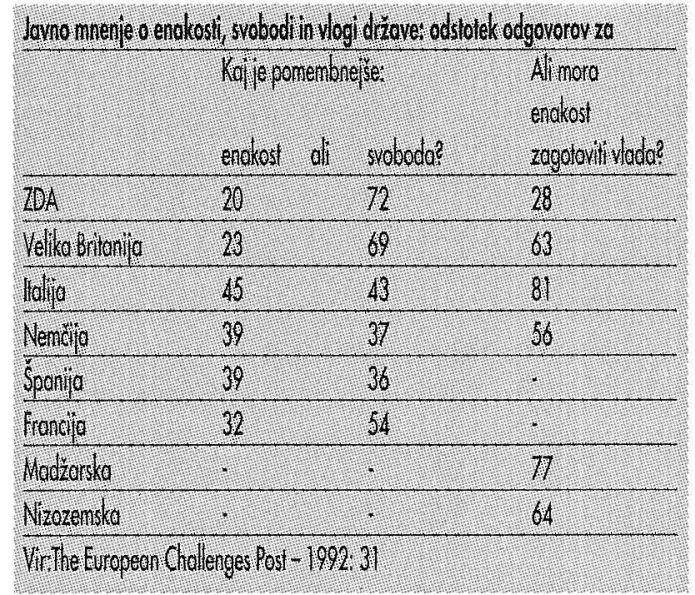

braževanjem preusmerjajo od materialističnih (zadovoljevanje primarnih potreb) in tradicionalističnih (tradicionalna družinska povezanost) $\mathrm{k}$ nematerialnim in bolj individualističnim.

Da sta solidarnost in družbena enakost evropski vrednoti, potrjujejo tudi javnomnenjske raziskave o enakosti in svobodi. Evropske države dajejo prednost enakosti, zanjo je odgovorna tudi vlada, medtem ko je npr. v ZDA svoboda veliko pomembnejša od enakosti ali vloge države pri njenem zagotavljanju.

\section{OKROGLA MIZA EVROPSKIH INDUSTRIALCEV}

V pogovoru za Okroglo mizo evropskih industrialcev (1995), v njem so sodelovali tudi rektorji evropskih univerz, so direktorji vodilnih podjetij in ustanov odgovarjali na vprašanje, kaj mislijo o prihodnjem šolskem kurikulumu. Njihovi odgovori so bili daleč od želja po iskanju poklicno usposobljenih specialistov. Poudarili so široko humanistično izobraževalno filozofijo. Zagovarjajo vsestransko izobrazbo (liberal education), strukturirano okrog treh ključnih področij kot spiralo, ki poteka v vseh človekovih obdobjih, od otroštva do pozne starosti. Takšna področja so:

- matematika, znanost, tehnologija (naravoslovje),

- humanistika,

- ekonomija, družboslovje.

To je seveda daleč od tega, kar uveljavljajo predstavniki iz sveta kapitala in dela, ki jih zanimajo usposobljenost $\mathrm{v}$ matematiki, pisanju in komunikaciji ter analitične spretnosti (tako imenovano temeljno znanje in usposobljenost).

Tudi v vseh drugih dokumentih mednarodne organizacije (OECD, EU, Unesco) napovedujejo, da bo postala Evropa (svet) učeča se skupnost, ki postavlja pred izobraževanje tri temeljne zahteve: socialno integracijo, povečevanje zaposljivosti, gospodarske neodvisnosti in učinkovitosti ter razvijanje znanja in usposobljenosti za »celostni razvoj posameznika in obvladovanje lastne usode (Učenje skriti zaklad, 1996: 93)«. Navajajo tudi vsebinska področja, kot so matematično analitične spretnosti, informacijsko in dokumentacijsko znanje, znanje s področja umetnosti, zdravja, 
državljanskih pravic, okolja, spretnosti izražanja in komuniciranja, kulturne dediščine, kulture miru, zdravja, varovanja okolja itn.

\section{AKCIJSKI NAČRT ZA PRIHODNOST}

Temeljne zahteve in naloge izobraževanja odraslih razčlenjuje Akcijski načrt za prihodnost, ki ga je sprejela Peta mednarodna konferenca o izobraževanju odraslih v Hamburgu leta 1997 v 10 izhodiščnih temah in njihovi povezanosti/soodvisnosti $z$ učenjem in izobraževanjem odraslih:

- povečevanje demokracije z bistvenim zboljšanjem okoliščin za učenje, $s$ povečanjem priložnosti državljanov za participacijo, za povečevanje produktivnosti in $\mathrm{z}$ ukoreninjenjem kulture enakopravnosti in miru;

- zboljšanje razmer za učenje odraslih in njegove kakovosti;

- zagotavljanje splošne pravice do pismenosti in temeljnega izobraževanja odraslih;

- zagotavljanje enakih možnosti za učenje in enakopravnosti med spoloma, krepitev priložnosti za ženske;

- spreminjajoči se svet dela (zagotovitev preživetja, družbene blaginje, kakovosti življenja);

- varovanje okolja, zdravja, razvoja prebivalstva;

- kulturni razvoj, vloga javnih občil in informacijske tehnologije;

- možnosti izobraževanja za vse; za različne skupine prebivalcev ( starejši, migranti, priseljeni, odrasli s posebnimi potrebami, obsojenci);

- ekonomika izobraževanja (zboljšanje financiranja izobraževanja odraslih);

- povečevanje mednarodnega sodelovanja in solidarnosti.

\section{SPOROČILO MINISTROV OECD}

Za naše razmere, razvojne ambicije in strateške cilje razvoja izobraževanja odraslih je temeljnega pomena Sporočilo ministrov OECD (OECD 1996: 21-24). Na konferenci v Parizu, januarja 1996, so ministri obravnavali vprašanja, zakaj je vseživljenjsko učenje ključno za nadaljnji razvoj držav OECD. V posebnem sporočilu za javnost so določili dve področji, na katerih je treba ukrepati, in sicer:

- osnove/podlage za vseživljenjsko učenje, ki jo zagotavljajo predšolski in šolski izobraževalni sistemi;

- vseživljenjsko učenje po začetnem izobraževanju, kjer bo treba še veliko storiti.

Sporočilo za javnost zajema štiri temeljne točke:

- »zavedamo se ključnega pomena vseživljenjskega učenja za bogatejše osebno življenje, hitrejšo ekonomsko rast in ohranjanje družbene povezanosti;

- strinjamo se s strategijami za vpeljevanje vseživljenjskega učenja:

- razvito predšolsko izobraževanje in izobraževanje mladine, ki daje temelje za učenje $v$ vseh obdobjih in okoliščinah;

- razvite poti za povezovanje učenja in dela in prehajanje med obema;

- spremenjena vloga in odgovornost vlad, socialnih partnerjev, razvite spodbude za posameznike, delodajalee in vlade za investiranje $\mathrm{v}$ vseživljenjsko učenje;

- potrebujemo učinkovitejše poti za to, da bomo ponudili vsakemu državljanu priložnost za učenje;

- cilj je ambiciozen, vendar si ne moremo privoščiti, da si ne bi prizadevali za njegovo uresničevanje«.

\section{STRATEGIJA RAZVOJA SLOVENIJE}

Temeljne prvine iz vseh naštetih dokumentov lahko najdemo tudi $\mathrm{v}$ dokumentih razvoja Slovenije. Strategija gospodarskega razvoja Slovenije (Potočnik, 1995) uvršča med ključne cilje hitrejšo gospodarsko rast $\mathrm{z}$ razvojnim dohitevanjem razvoja razvitih evropskih držav, večjo tekmovalnostjo, včlenjevanje $\mathrm{v}$ evropske povezave in »trajno obstojnost gospodarskega razvoja $\mathrm{z}$ okoljskega, socialnega in nacionalno kulturnega vidika «. Določa štiri temeljne razvojne dejavnike: človeški dejavnik, fizični kapital, tehnološki napredek in podjetništvo. Kar zadeva razvojne spodbude ima izobraževanje poglavitno vlogo med dejavniki, ki vplivajo na oblikovanje človeškega kapitala in njegov razvoj.

Našo strategijo lahko povežemo $\mathrm{z}$ ministrskim sporočilom za javnost iz Pariza $\mathrm{v}$ tistih delih besedila, o katerih je govor o »izobraževanju mladih za doseganje različnih stopenj formalne izobrazbe « ter »izobraževanju odraslih in neformalne oblike izobraževanja « (Potočnik, str. 72 in 73). Poudarja tudi druge de- 


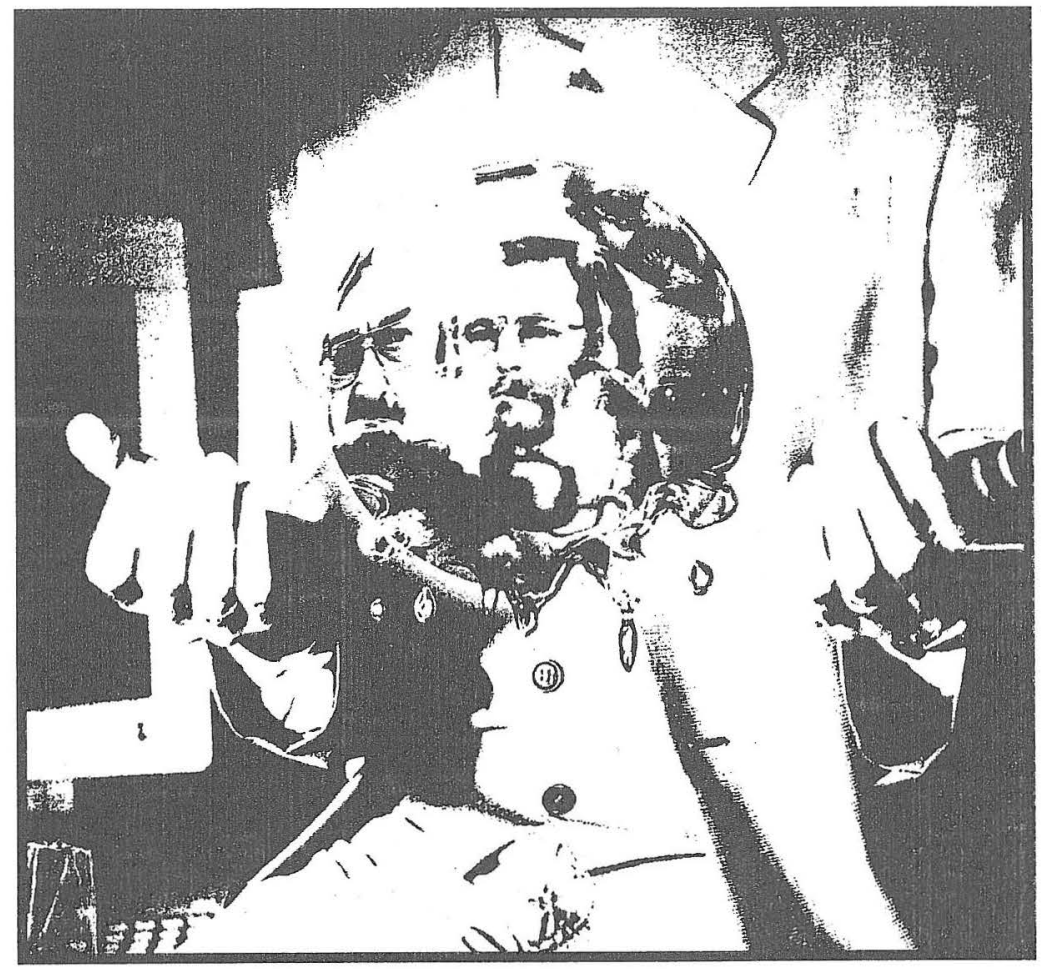

javnosti, kot so vzgoja v družini, kultura, telesna kultura in zdravstvo, ki vplivajo na proizvodno in storitveno dejavnost, nujne pa so tudi za zadovoljevanje osebnih potreb ljudi, ohranjanje in razvijanje človekovih sposobnosti ter večje sodelovanje odraslih $\mathrm{v}$ dejavnem življenju. Med najpomembnejšimi nalogami strategije gospodarskega razvoja sta tudi »zavzemanje za enakost med ljudmi « ter razvijanje kolektivnega dogovarjanja in participacije v upravljanju (str. 31, 32). Razvojni scenarij (t. i. razvojni scenarij Plus) naj bi ekonomska politika podprla tudi z novimi državnimi investicijskimi programi, ki bi bili usmerjeni v izo-

Uveljavljanje strategije vseživljenjskega ǔ̌enja razbija tradicionalno šolo. braževanje, tehnološki razvoj, raziskovalno in razvojno dejavnost, v gospodarsko infrastrukturo in sanacijo okolja (Strmšnik, 1995).

Nacionalni raziskovalni program (MZT, 1996) prednost-

no obravnava povečevanje uporabe znanja za gospodarski, socialni, kulturni in okoljevarstveni razvoj Slovenije.

Strokovne podlage za pripravo nacionalnih programov na drugih družbenih in gospodarskih področjih (Strokovne podlage za nacionalni program izobraževanja odraslih, Izobraževanje odraslih $\mathrm{v}$ drugih nacionalnih..., 1995) vsebujejo določila o izobraževanju odraslih, in to ne le za zaposlene na svojem področju, temveč tudi za prebivalce, ki uporabljajo storitve zaposlenih na teh področjih, v različnih vlogah, kot npr.:

- širjenje kulturne vzgoje in kulturnega izobraževanja, obveznost kulturnih ustanov, da $\mathrm{z}$ andragoško dejavnostjo širijo zanimanje za našo kulturno dediščino in njeno kulturno vrednost, razvijanje splošne zavesti o pomenu kulturne dediščine, razvoj ljubiteljske kulture;

- preventivno zdravstveno izobraževanje,

- izobraževanje delovne sile v kmetijstvu, izobraževanje za varovanje gozdov;

- izobraževanje za skladnejši regionalni razvoj itn.

\section{IZOBRAŽEVANJE ODRASLIH V PODROČNI ZAKONODAJI}

Poleg delovne in socialne zakonodaje, ki določata pravice in obveznosti zaposlenih in brezposelnih do izobraževanja, vsebuje določila o izobraževanju odraslih še 347 veljavnih zakonov (Strokovne podlage za nacionalni program izobraževanja odraslih: Analiza veljavnih..., ACS, 1995). Ti zakoni večidel urejajo pogoje izobrazbe in strokovne usposobljenosti, ki jih morajo izpolnjevati zaposleni (95,2 \% zakonov), da lahko opravljajo delo (ti programi niso predmet urejanja nacionalnega programa izobraževanja odraslih). Zajemajo tudi določbe o splošnem izobraževanju/prosvetljevanju za ozaveščanje o vprašanjih, pomembnih za razvoj teh področij (npr.: urejanje prostora in varstva okolja, varovanje zdravja). Tovrstno izobraževanje bo urejal nacionalni program izobraževanja odraslih. Izobraževanje urejajo tudi konvencije Mednarodne organizacije dela (Konvencije št. 140, 142, 168), katerih podpisnica je Slovenija ali pa bo to še postala.

\section{VSEŽIVLJENISKO UČENJE ZA VSE}

Izobraževanju odraslih pripisujejo torej v Evropi in pri nas pomembno razvojno vlogo, pričakovanja pa bo lahko upravičilo le z uveljavljanjem koncepta in strategije »vseživljenjsko učenje za vse«.

Ta koncept je pri nas že "priznan « v zahtevi po nenehnem poklicnem izobraževanju, ki ga zahtevajo znanstveni in tehnološki napredek ter spreminjanje proizvodnih procesov zaradi 
povečevanja tekmovalnosti slovenskega gospodarstva. Toda zasnova in strategija vseživljenjskosti pomenita več - uveljavljanje »večrazsežnostnega izobraževanja «: učenje za »živo udejanjanje državljanstva ", posameznikov "celostni razvoj «, "vedenje o življenju z drugimi «, "osebno ustvarjalnost «, preprečevanje neenakosti v možnostih izobraževanja (Učenje: skriti zaklad 1995: 93-95).

To »večrazsežnost « lahko uresničujemo le s koncepcijo in strategijo vseživljenjskosti učenja, ki zagotavlja:

- razvoj človekovih zmožnosti; spodbuja posameznike in jim daje »moč, da si pridobivajo znanje, vrednote in spretnosti, ki jih bodo potrebovali vse življenje in jih bodo uporabljali $\mathrm{z}$ zaupanjem, ustvarjalnostjo in veseljem $\mathrm{v}$ vseh vlogah, okoliščinah in okoljih « (Unesco, 1997);

- razvoj znanja in usposobljenosti za gospodarski, tehnološki, kulturni in socialni razvoj na vseh ravneh zahtevnosti, spoštovanje človekovih pravic, razvoj demokracije, ekonomsko učinkovitost podjetij in gospodarstva;

- zmanjšanje in odpravljanje družbene zapostavljenosti nekaterih skupin prebivalstva;

- spodbude za razvoj družbenopovezovalnih dejavnosti v lokalnem okolju.

Uresničevanje te strategije prinaša spremembe $\mathrm{v}$ celoten vzgojno-izboraževalni sistem: korenite spremembe $\mathrm{v}$ izobraževanje in delo učiteljev, vnovično definiranje izobraževalnih vsebin in učnih procesov (ne zaradi družbenih in gospodarskih sprememb, temveč zaradi perspektiv vseživljenjskega učenja); tesnejše povezovanje in večjo enakost pri vrednotenju poklicnega in splošnega izobraževanja, razvijanje zanimanja in sposobnosti ter motivacije za učenje pri vseh ljudeh $\mathrm{v}$ vseh življenjskih obdobjih, bistveno več denarja in prerazdelitev virov in porabe denarja.

Te spremembe seveda vnašajo nemir v tradicionalno izobraževalno okolje. Razumsko slepilo, da lahko šola sama, četudi bo še tako dobro "prenovljena ", zadosti vsem potrebam po izobraževanju, se je že precej razblinilo. Vendar pa se $\mathrm{v}$ praksi, politiki in ukrepih za pospeševanje razvoja izobraževanja odraslih uveljavlja predvsem "vseživljenjsko učenje " za potrebe poklica in zaposlitve in manj za potrebe na drugih področjih človekovega življenja in dela.
$\mathrm{Z}$ izbiro in predstavitvijo podlag za določanje strateških in operativnih ciljev nacionalnega programa izobraževanja odraslih smo želeli pripraviti prostor za dvoje:

- za uveljavljanje prepričanja, da je vseživljenjsko učenje bistvena, in ne le instrumentalna vrednota; za uveljavljanje potrebe po splošnem dostopu do izobraževalnih priložnosti in za priznavanje pomena neformalnega izobraževanja;

- za uveljavljanje enakopravnejšega obravnavanja obeh vlog izobraževanja: produktivne vloge, ki jo kvantitativno merimo s finančnimi donosi (do $25 \%$ višja ekonomska rast); potrošne vloge, pri kateri so finančni in nefinančni donosi težko izmerljivi. Pokažejo pa se $\mathrm{v}$ delovanju družine, posameznika, v strpnosti in razumevanju drugačnosti, bogatenju tradicije in kulture, $\mathrm{v}$ kakovosti življenja, načinu preživljanja prostega časa, večjem vključevanju starejšega prebivalstva $\mathrm{v}$ aktivno prebivalstvo in tudi $\mathrm{v}$ zaposlovanje (Kidrič, 1995); ta vloga je dejansko potisnjena na obrobje družbenega zanimanja ali ukrepanja kot osebna zadeva posameznika.

Tako kakor mora pri izobraževanju mladih šola razvijati spomin in mišljenje, občutek za lepoto, sposobnost vrednotenja in presojanja, fizične zmogljivosti in sposobnosti sporazumevanja, tako mora izobraževanje odraslih dajati znanje in usposabljati ne samo za gospodarski razvoj, ampak tudi za politično in kulturno vrednostno dimenzijo (Kovač, 1995: 31): razvijanje temeljnih demokratičnih vrednot, samozaupanje, obvladovanje lastne usode pri delu in v širši skupnosti, uveljavljanje javne morale družbenih in gospodarskih sprememb.

Na načelni ravni in pri ciljih vzgoje in izobraževanja tako mladine kakor odraslih najdemo vse vidike, $v$ izpeljavi načel pa se ta celotnost zmeraj znova izgublja. Zato smo v vsebinskih izhodiščih za oblikovanje ciljev nacionalnega programa izobraževanja odraslih postavili $\mathrm{v}$ ospredje pomen izobraževanja odraslih v njegovih socialnih in kulturnih razsežnostih, torej vlogo, ki mu jo priznavajo tudi razvite zahodnoevropske države in njihov poslovni svet, pa tudi naša strategija gospodarskega razvoja.

Prihodnjič bomo predstavili smeri razvoja izobraževanja odraslih in njegov zdajšnji položaj $s$ stališča uresničljivosti strateških in operativnih ciljev, ki jih določamo $v$ strokovnih podlagah za nacionalni program tega področja. 


\section{LITERATURA}

Akcijski načrt za prihodnost (1997). Peta mednarodna konferenca o izobraževanju odraslih, Hamburg.

Dokumenti mednarodnih organizacij: OECD, Documents, Centre for Educational Research and Innovation, Learning Beyond Schooling, New Forms of Supply and New Demands (1995), Paris, OECD Publications. White Paper on Education and Training, Teaching and Learning, Towards the Learning Society (1995), Evropska zveza. Medium - Term Strategy 1996-2001 (1995), Unesco, Paris.

Drofenik, O.; Pretnar Z. (1996). Izobraževanje odraslih v drugih nacionalnih programih, Strokovne podlage za nacionalni program izobraževanja odraslih. Ljubljana, ACS.

European Challenges Post - 1992 Shaping Factors, Shaping Actors (1993) ur.: Jacquemin, A. and Wright, D.

Gorz, A. (1989). Critique of Economic Reason, London, Verso.

Kidrič, D. (1995). Socialnovarstvena mreža. V: Prostor, okolje, socialna varnost. Strategija gospodarskega razvoja, Zavod za makroekonomske analize in razvoj.

Kovač, B. (1995). Izhodiščne vrednote in izzivi gospodarskega razvoja Slovenije. V: Utemeljitev, vrednote in cilji. Strategija gospodarskega razvoja. Zavod za makroekonomske analize in razvoj.

Lifelong Learning for All, Meeting of the Education Committee at Ministerial Level, 16-17 January 1996, Organisation for Economic Cooperation and Development, 1996.

Pirnat, R. et al (1995). Analiza veljavnih slovenskih zakonov, ki urejajo problematiko izobraževanja odraslih. Strokovne podlage za nacionalni program izobraževanja odraslih, Ljubljana, ACS.

Potočnik, J.; Senjur, M.; Štiblar, F. (1995). Približevanje Evropi - rast, konkurenčnost in integriranje. Strategija gospodarskega razvoja, Zavod za makroekonomske analize in razvoj.

Sočan, L. (1995): Konkurenčnost. V: Splošni pogoji za gospodarski razvoj. Strategija gospodarskega razvoja. Zavod za makroekonomske analize in razvoj.
Strmšnik, I.; Jevševar, J. (1995). Scenarij gospodarskega razvoja Slovenije do leta 2000. Strategija gospodarskega razvoja. Zavod za makroekonomske analize in razvoj.

Svetlik I. (1995). Zaposlovanje in gospodarski razvoj. V Faktorji gospodarskega razvoja. Strategija gospodarskega razvoja. Zavod za makroekonomske analize in razvoj. Učenje: skriti zaklad, Poročilo mednarodne komisije o izobraževanju za enaindvajseto stoletje, pripravljeno za Unesco (1996). Ljubljana, Ministrstvo za šolstvo in šport.

${ }^{1}$ Vsebinske podlage je obravnaval Strokouni svet za izobraževanje odraslib na svoji seji, maja 1997. leta. Predstavljene so bile tudi v Tednu vseživljenjskega učenja '97 na strokounem srečanju v ACS.

${ }^{2}$ Iz Belgije, Danske, Francije, Nemčije, Grčije, Irske, Italije, Luksemburga, Nizozenaske, Portugalske, Španije in Velike Britanije.

3 Gorz (Gorz 1989: 225-226) napoveduje, da se bodo kljub precejšnjim spremembam v ideologiji, organizaciji in distribuciji dela dozdajšnje usmeritve poznale $v$ družbeni oblikovanosti, $k i$ se bo zelo razlikovala od te, $k i$ jo zahteva modernizacija, pravzaprav vsestranska izurjenost. Prihodnost bo, po njegovih napovedih, aktivno prebivalstvo razdelila takole:

- 25 \% usposobljene (skilled) delovne sile bo imelo redno zaposlitev v velikih podjetjih in bo zavarovanih s kolektivno pogodbo o plačab;

- $25 \%$ bo obrobnib delavcev $z$ nezanesljivo, slabo plačano službo, ki ne zahteva kvalifikacije, njihova zaposliivost se bo spreminjala po željah njibovib delodajalcev in fluktuaciji na trgu delovne sile;

- $50 \%$ bo delno zaposlenih, nezaposlenih in marginaliziranih delavcev, ki bodo posegali po priložnostnih, sezonskih in občasnih zaposlitvah (Gorz jih na primeru novih delovnih mest $v$ ZDA lod 13 do 15 milijonov $v$ 10-letnem obdobju) na področju osebnih storitev (varuške, nočni varnostniki, snažilke, natakarii, osebje $v$ lokalih s bitro brano, strežniki $v$ bolnišnicah itn.) primerja z nekdanjimi sužnji in služinčadjo . 